University of Nebraska - Lincoln

DigitalCommons@University of Nebraska - Lincoln

\title{
Chemical openness and potential for misinterpretation of the solute environment of coastal sabkhat
}

\author{
Warren W. Wood \\ Michigan State University \\ Ward E. Sanford \\ U.S. Geological Survey \\ Shaun K. Frape \\ University of Waterloo, Waterloo, Ontario, Canada
}

Follow this and additional works at: https://digitalcommons.unl.edu/usgsrye

Part of the Geochemistry Commons

Wood, Warren W.; Sanford, Ward E.; and Frape, Shaun K., "Chemical openness and potential for misinterpretation of the solute environment of coastal sabkhat" (2005). Geochemistry of Sulfate Minerals: A Tribute to Robert O. Rye. 14.

https://digitalcommons.unl.edu/usgsrye/14

This Article is brought to you for free and open access by the US Geological Survey at DigitalCommons@University of Nebraska - Lincoln. It has been accepted for inclusion in Geochemistry of Sulfate Minerals: A Tribute to Robert O. Rye by an authorized administrator of DigitalCommons@University of Nebraska - Lincoln. 


\title{
Chemical openness and potential for misinterpretation of the solute environment of coastal sabkhat
}

\author{
Warren W. Wood ${ }^{\mathrm{a}, *}$, Ward E. Sanford ${ }^{\mathrm{b}}$, Shaun K. Frape \\ ${ }^{a}$ Room 206 Nat. Sciences Building, Michigan State University, E. Lansing, Michigan 48824, USA \\ ${ }^{\mathrm{b}}$ MS 431 National Center, U.S. Geological Survey, Reston, Virginia 20192, USA \\ ${ }^{\mathrm{c}}$ Department of Earth Sciences, University of Waterloo, Waterloo, Ontario, Canada N2L $3 G 1$
}

Accepted 1 June 2004

\begin{abstract}
Sabkha deposits in the geologic record are commonly used to interpret the environmental conditions of deposition. Implicit in this use is the assumption that the solute system is chemically closed, that is, the authigenic minerals represent the composition of the fluids in their environment of origin. Thermodynamic and mass-balance calculations based on measurements of water and solute flux of contemporary Abu Dhabi coastal sabkha system, however, demonstrate that the system is open for sodium and chloride, where nearly half of the input is lost, but closed for sulfur, where nearly $100 \%$ is retained. Sulfur and chloride isotopes were consistent with this observation. If these sabkha deposits were preserved in the geologic record, they would suggest a solute environment rich in sulfate and poor in chloride; yet the reverse is true. In most coastal-sabkha environments, capillary forces bring solutes and water to the surface, where the water evaporates and halite, carnallite, sylvite, and other soluble minerals are precipitated. Retrograde minerals, such as anhydrite, calcite, dolomite, and gypsum, however, precipitate and accumulate in the capillary zone beneath the surface of the coastal sabkha. Because they possess relatively low solubility and are below the surface, these retrograde minerals are protected from dissolution and physical erosion occurring from infrequent but intense rainfall events. Thus, they are more likely to be preserved in the geological record than highly soluble minerals formed on the surface. (C) 2004 Elsevier B.V. All rights reserved.
\end{abstract}

Keywords: Abu Dhabi; Sabkha; Sedimentary Petrology; Hypersaline; Anhydrite

\section{Introduction}

In attempting to recreate the depositional environment of a sedimentary sequence, one typically

* Corresponding author. Tel.: +1 517355 4629; fax: +1 517 3538787.

E-mail address: wwwood@msu.edu (W.W. Wood). evaluates the authigenic minerals preserved in the geologic record and infers the composition of fluid and temperature under which the minerals could have formed. Implicit in this process is the assumption of a closed system for solutes. To test the validity of this assumption, a modern coastal sabkha in the Emirate of Abu Dhabi was evaluated. Mass balance calculations demonstrated that the system is open for chloride, but

0009-2541/\$ - see front matter (C) 2004 Elsevier B.V. All rights reserved. doi:10.1016/j.chemgeo.2004.06.043

This article is a U.S. government work, and is not subject to copyright in the United States. 
closed for sulfate, although the observed authigenic minerals suggest a solute source high in sulfate and low in chloride concentrations. Thus, the geologic record must be evaluated in light of system openness to determine the environment from which the minerals were derived.

Sanford and Wood (2001) discuss the hydrogeology, and Wood et al. (2002) address the origin of solutes of this sabkha system. This paper focuses on the origin and distribution of authigenic minerals in the coastal sabkha in an effort to evaluate quantitatively the solute-mass flux from which minerals are deposited in and on the coastal sabkha, and to compare that flux over time with the observed mass distribution of minerals. The difference between the calculated and observed mass gives a measure of the chemical openness of the system to different solutes, and thus gives some insight as to why the mineral assemblage in the Abu Dhabi coastal sabkha does not reflect the solute ratios of solutions from which the assemblage was derived.

\section{Hydrogeological framework}

Sabkhat (Arabic plural for "salt flats" or "salt surfaces") are ubiquitous features in many arid and semiarid areas of the world and constitute approximately $1 \%$ of the land surface. Typically, they are covered with halite and other soluble chloride and nitrate minerals (Smoot and Lowenstein, 1991; Rosen, 1994). The word sabkha has been used in geological literature for a mineralogy and texture that imply a three-dimensional system (Gary et al., 1972). "Sabkha" as used in this paper recognizes the original Arabic two-dimensional surface as part of a threedimensional system, similar to the definition given by Kinsman (1969). The coastal sabkha in the Emirate of Abu Dhabi is exposed as a strip approximately 300 $\mathrm{km}$ long and $15 \mathrm{~km}$ wide (Fig. 1).

Polygons of halite approximately $1 \mathrm{~m}$ across and 1 to $2 \mathrm{~cm}$ thick, bordered by pressure ridges 2 to $3 \mathrm{~cm}$ high, cover much of the sabkha surface. The area is flat, with a topographic and groundwater gradient of approximately 1:5000 toward the Arabian Gulf, and with a depth between 0.5 and $1 \mathrm{~m}$ to groundwater. The Holocene rise of sea level starting at 18,000 years BP filled the Gulf to its present level by approximately
7000 years BP. As the sea level rose, sand from eolian Pleistocene dunes that existed in the area now occupied by the Gulf was incorporated into the Abu Dhabi Formation, upon which the coastal sabkha has developed (Evans, 1995). The eolian sand framework of the Abu Dhabi aquifer consists of uniform, finegrained sand $(0.16-0.22 \mathrm{~mm})$ composed of $60 \%$ detrital carbonates and $35 \%$ quartz, with minor amounts of feldspar, anhydrite, and heavy minerals. Laboratory analysis of repacked sand yields a porosity of 0.38 . Because of the uniformity and uncemented nature of the eolian sand, it is hypothesized that this value is also representative of the in situ porosity of the Abu Dhabi Formation.

The Abu Dhabi Formation, upon and within which the coastal sabkha is formed, is generally wedgeshaped, with zero thickness at the proximal edge and increasing to approximately $15 \mathrm{~m}$ near the coast (Butler, 1969; Fig. 2). These sands overlie Pleistocene and Miocene clastic rocks and older Tertiary evaporites in the coastal areas. The presence of paleochannels or erosional remnants of these rocks increases or decreases the thickness of the Abu Dhabi Formation. Superimposed on the Abu Dhabi Formation is the Evans Member, a thin $(<2 \mathrm{~m})$, wedgeshaped sand that starts midway between the proximal and distal edges of the sabkha and extends to the coast. The rate of progradation of the Evans Member into the Arabian Gulf is between 1 and $2 \mathrm{~km}$ every thousand years (Evans, 1995).

Authigenic anhydrite, calcite, dolomite, and gypsum are seldom present in significant quantities on the surface, and are largely confined to the capillary zone, which extends 0.5 to $1 \mathrm{~m}$ above the water table. In the areas investigated, most of the anhydrite consists of silt- or clay-size grains that give it a "toothpaste" consistency. Nodules of "chicken wire" anhydrite typically underlie this structureless anhydrite. Crystals of equidimensional gypsum up to 5 $\mathrm{mm}$ in length exist within the vertical range of the water-table fluctuations (Fig. 3). Minor amounts of authigenic calcite and dolomite are intermixed with the anhydrite. Visual inspection of exploration pits and auger cuttings suggests that anhydrite and gypsum have occluded approximately half of the porosity of the upper meter (Fig. 3).

Crusts of halite and other chloride and nitrate minerals form on the surface in different places, with 


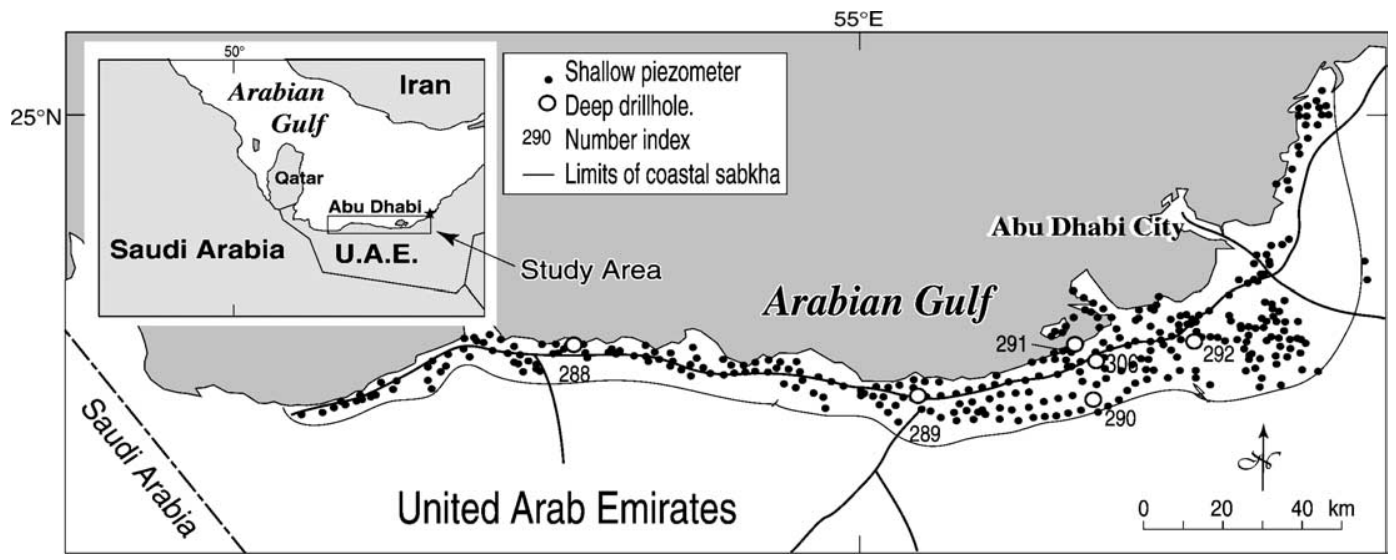

Fig. 1. Location of the coastal sabkha of the Emirates of Abu Dhabi, United Arab Emirates (U.A.E.). Points indicate chemical sampling locations within the aquifer underlying the sabkha (modified from Wood et al., 2002).

different thickness, and at different times throughout the year. Chloride minerals, however, are not readily apparent in the capillary zone or below the water table. Thin lines of dark-colored material (buried algal mats?) are observed only in the prograded Evans Member. X-ray diffraction identifications have shown that most of the evaporite minerals on the surface are halite, with trace amounts of carnallite, anhydrite, sylvite $[\mathrm{KCl}]$, and antarcticite (Daniel Webster, USGS, written communication, 2002). Results from chemical analyses of the soluble salts from the surface crusts are given in Table 1. Samples were collected from the surface by carefully lifting sections of the mineral crust and placing them in poly-sealed bags, assigning identifying numbers, and transporting them to the laboratory. Solute concentrations were determined after dissolution of the crust in distilled water by standard analytical methods (Wood et al., 2002). These analyses illustrate the large mass of chloride relative to sulfur on the sabkha surface, over a wide geographic area of several thousand square kilometers and are thus of a regional not local significance.

The average annual groundwater temperature at the water table in the sabkha is approximately $32{ }^{\circ} \mathrm{C}$; the temperature on the surface can exceed $65{ }^{\circ} \mathrm{C}$, thus giving a gradient of nearly $30{ }^{\circ} \mathrm{C} / \mathrm{m}$. The condition is reversed in the winter, however, with a negative temperature gradient of approximately $15{ }^{\circ} \mathrm{C} / \mathrm{m}$.

The capillary zone (rise of water above the water table) is critical to the development of the authigenic minerals in this environment. The zone results from two forces: mutual attraction between water molecules (hydrogen bonding), and molecular attraction between water and the different minerals that form the aquifer. Thus, for any given mineral, the smaller the interstitial pore size, the greater the vertical rise of water. The capillary rise (also called the "zone of tension saturation" or "wetting front") is the saturated zone above the water table in which the interstitial pore spaces are completely filled with water, but the water

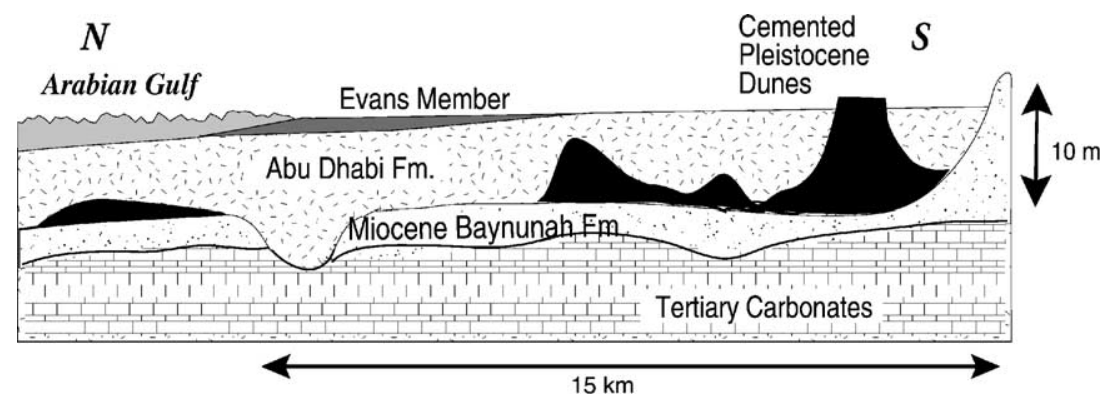

Fig. 2. Generalized geological cross section of the coastal sabkha of Abu Dhabi (modified from Wood et al., 2002). 


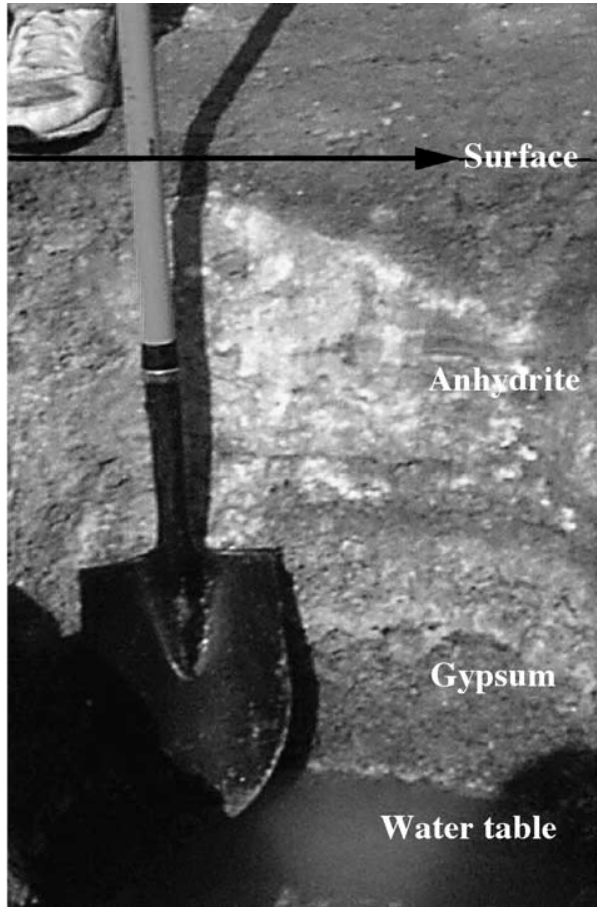

Fig. 3. A vertical profile of a representative test pit, showing the surface, capillary zone containing anhydrite and gypsum, and the water table in the coastal sabkha of Abu Dhabi.

is under less than atmospheric pressure. There can be no evaporation within this zone of tension saturation because water completely fills the pore spaces. Above the zone of tension saturation is a zone in which the water film and a gas phase exist in the interstitial pore space. The relative humidity of this gas phase is, however, equal to the thermodynamic activity of water, and no evaporation occurs. Evaporation occurs at, or a few centimeters below, the surface where the relative humidity of the gas phase is less than the thermodynamic activity of the water. Thus, minerals formed in the lower two environments are not evaporites, but are thermalites. A thermalite is herein defined as a mineral formed by changes in temperature independent of other processes that alter the thermodynamic properties of the solution.

The average residence time for water in the capillary zone of $1 \mathrm{~m}$ thickness is calculated using Eq. (1):

$R_{\mathrm{w}}=V S \theta / E$,

where $R_{\mathrm{w}}$ is the residence time for water (T), $V$ is the volume of the capillary zone $\left(\mathrm{L}^{3}\right), \theta$ is the total porosity (dimensionless), $S$ is the water saturation porosity (dimensionless), and $E$ is the evaporation flux rate $\left(\mathrm{L}^{3} \mathrm{~T}^{-1}\right)$, where $\mathrm{L}$ is length, and $\mathrm{T}$ is time. With observed values of the parameters $\left(V=1 \mathrm{~m}^{3}\right.$, $\theta=0.38, S=0.5$, and $E=0.065 \mathrm{~m}^{3}$ year $\left.^{-1}\right)$, the residence time for water in the capillary zone is between 1 and 2 years.

The conceptual model proposed herein for mineral deposition on most coastal sabkhat suggests that water and solutes are transported upward by capillary force from the shallow water table in response to water evaporating at the surface. The water is removed, leaving salts that form halite $[\mathrm{NaCl}]$, carnallite $\left[\mathrm{KMgCl}_{3} \cdot 6 \mathrm{H}_{2} \mathrm{O}\right]$, antarcticite $\left[\mathrm{CaCl}_{2} \cdot 6 \mathrm{H}_{2} \mathrm{O}\right]$, and other soluble minerals. Minerals exhibiting retrograde solubility, however, such as anhydrite $\left[\mathrm{CaSO}_{4}\right]$, calcite $\left[\mathrm{CaCO}_{3}\right]$, dolomite $\left[\mathrm{CaMg}\left(\mathrm{CO}_{3}\right)_{2}\right]$, and gypsum $\left[\mathrm{CaSO}_{4} \cdot 2 \mathrm{H}_{2} \mathrm{O}\right]$, are precipitated below the surface as

Table 1

Chemical analyses $\left(\mu \mathrm{g} \mathrm{g}^{-1}\right)$ of soluble surface crusts from the Abu Dhabi sabkha

\begin{tabular}{|c|c|c|c|c|c|c|c|c|c|c|c|c|}
\hline Site name & UTM easting & UTM northing & UTM zone & $\mathrm{Ca}$ & $\mathrm{Mg}$ & $\mathrm{Na}$ & $\mathrm{K}$ & $\mathrm{Sr}$ & $\mathrm{SiO}_{2}$ & $\mathrm{Cl}$ & $\mathrm{NO}_{3}$ & $\mathrm{SO}_{4}$ \\
\hline $\mathrm{C}$ & 609434 & 2647570 & 39 & 2792 & 2204 & 80,000 & 1469 & 73 & 13 & 144,521 & 212 & 6527 \\
\hline A & 628728 & 2650813 & 39 & 6163 & 3698 & 100,000 & 2157 & 154 & 26 & 195,520 & 800 & 6703 \\
\hline E & 654839 & 2665053 & 39 & 2130 & 913 & 91,000 & 1126 & 33 & 10 & 157,286 & 435 & 5915 \\
\hline G & 709433 & 2266465 & 39 & 1679 & 1068 & 130,370 & 1373 & 37 & 78 & 386,032 & 516 & 9734 \\
\hline B & 733623 & 2661480 & 39 & 3586 & 14,943 & 101,000 & 897 & 105 & 18 & 197,252 & 215 & 9661 \\
\hline $\mathrm{F}$ & 734060 & 2653098 & 39 & 2541 & 291 & 15,000 & 598 & 36 & 16 & 25,527 & 316 & 8343 \\
\hline TR-099 & 777530 & 2655420 & 39 & 5895 & 1474 & 106,000 & 1832 & 95 & 17 & 228,300 & 543 & 10,506 \\
\hline GWP-289 & 777587 & 2655712 & 39 & 4941 & 898 & 112,000 & 1422 & 85 & 19 & 248,967 & 467 & 9278 \\
\hline D & 794944 & 2661406 & 39 & 6870 & 1754 & 93,000 & 1169 & 105 & 21 & 169,117 & 493 & 10,176 \\
\hline Abu -110 & 205454 & 2670505 & 40 & 5487 & 968 & 136,330 & 1614 & 97 & 24 & 419,991 & 233 & 9915 \\
\hline RP-6 & 205638 & 2670541 & 40 & 1305 & 657 & 13,800 & 600 & 32 & 5 & 40,277 & 52 & 2651 \\
\hline RP-1 & 207424 & 2668784 & 40 & 3455 & 2356 & 12,050 & 1286 & 53 & 17 & 38,643 & 147 & 5531 \\
\hline RP-5 & 210950 & 2655364 & 40 & 626 & 746 & 11,340 & 373 & 69 & 33 & 26,101 & 213 & 1950 \\
\hline
\end{tabular}


a result of increasing temperature as the solutes move from the groundwater through the capillary zone toward the surface during the summer months.

\section{Water and solute transport}

Wood et al. (2002) have shown that most of the solutes in the Abu Dhabi aquifer are derived from the underlying Tertiary brines, whereas most of the water is a result of direct recharge of precipitation on the sabkha surface (Sanford and Wood, 2001). Consider a rectilinear volume of Abu Dhabi aquifer perpendicular to the coast and defined as $1 \mathrm{~m}$ wide, $10 \mathrm{~m}$ deep, and $10 \mathrm{~km}$ long. Hydrological analysis suggests that each year within this rectilinear volume, less than $1 \mathrm{~m}^{3}$ of water enters and exits by lateral groundwater flow, 45 $\mathrm{m}^{3}$ of water enter by upward vertical leakage, and 640 $\mathrm{m}^{3}$ of water enter by recharge from rainfall. Approximately the same amount is lost each year by evaporation (Sanford and Wood, 2001). In contrast, $100 \mathrm{~kg}$ of solute enter through lateral groundwater flow, $200 \mathrm{~kg}$ are discharged to the Gulf through lateral groundwater flow, rainwater introduces $15 \mathrm{~kg}$, and upward vertical leakage introduces $3700 \mathrm{~kg}$ (Wood et al., 2002). Water has a residence time of approximately 50 years, whereas solutes have a residence time of approximately 26,000 years in the sabkha.

Because of the low values of hydraulic conductivity and gradient, only a small mass of total solutes that have entered the Abu Dhabi Formation have dis-

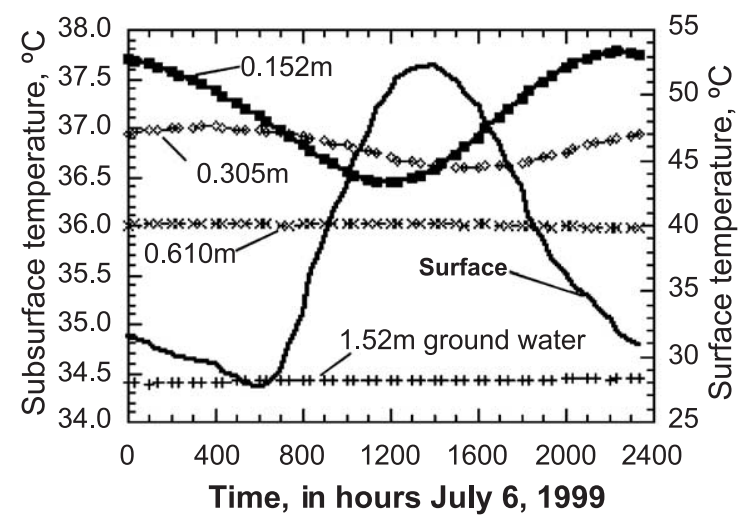

Fig. 4. One day temperature record of the surface, at various depths in the capillary zone, and of groundwater in the coastal sabkha of the Emirates of Abu Dhabi.

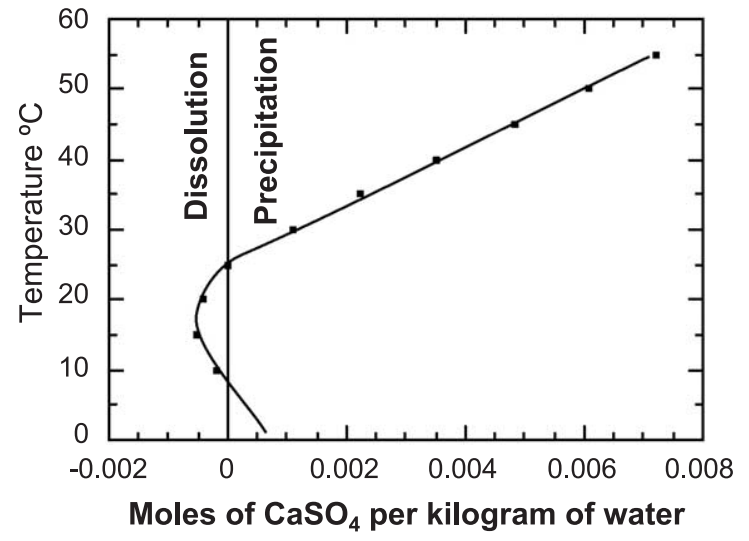

Fig. 5. Moles of $\mathrm{CaSO}_{4}$ precipitated per kilogram of water as a function of temperatures for a representative solute sample from the sabkha of the Emirates of Abu Dhabi.

charged to the Gulf. Thus, solute concentrations increase over time as a result of the addition of new solutes from the underlying Tertiary formations, lateral groundwater flow, and the recycling of soluble salts returned by surface recharge. Hydraulic potential, density, and Rayleigh numbers calculated from 12 pairs of piezometers at the top and bottom of the aquifer suggest vertical mixing (Sanford and Wood, 2001). The observation that tritium exists throughout the vertical profile (McKenzie et al., 1980) is consistent with this vertical circulation and the short residence time of water in the sabkha.

Water and solutes in the coastal sabkha water are close to or at thermodynamic equilibrium with respect to anhydrite, calcite, gypsum, and halite in most of the 192 water samples evaluated. It is proposed that precipitation of retrograde minerals occurs in the summer as the water warms during its transport to the surface. To evaluate the thermal gradient, the temperature of the surface, and the temperature at three depths in the capillary zone and one depth in shallow ground were collected at 15-min intervals for 9 months. A representative summer day (July 6, 1999) illustrates a positive gradient of approximately $25^{\circ} \mathrm{C} / \mathrm{m}$ (Fig. 4).

Reverse thermal gradient in the winter permits dissolution of some of the previously precipitated retrograde minerals. Because the negative thermal gradient is less in the winter than in the summer with nearly the same water flux, the water does not have the capacity to dissolve all of the mineral mass that was precipitated in the preceding summer. Thus, there is a 
net accumulation of these retrograde minerals in the capillary zone. This analysis assumes that the equal winter and summer water flux found by Sanford and Wood (2001) is representative of the long-term environment. The difference in mass precipitated and dissolved as a function of temperature is illustrated for anhydrite (Fig. 5) and defines the relatively small temperature range during which dissolution in winter can occur.

\section{Solute mass balance}

Comparison between the mass introduced by the vertical solute fluxes and the observed mineral accumulation corroborates the proposed capillary transport model. Consider a saturated vertical column $1 \times 1 \times 9 \mathrm{~m}$, with a porosity of 0.38 . One pore volume of this column occupies $3.4 \mathrm{~m}^{3}$, or $3,420,000 \mathrm{~cm}^{3}$. The underlying Tertiary brines have an average sulfate concentration of $4.7 \mathrm{~g} \mathrm{l}^{-1}$ (Table 2). Solute samples in Table 2 were collected and analyzed by methods described in Wood et al. (2002). Table 2 provides samples from a wide geographic range of several hundred kilometers illustrating that data are not a local phenomena. It is known from the hydrology that the input solutes from the underlying brine would have been concentrated approximately seven times since the aquifer was formed (Sanford and Wood, 2001). Thus, if the water flux and sulfate concentration have remained constant over 7000 years, approximately $33 \mathrm{~g}^{-1}$ of sulfate would have been delivered to the control volume. The observed dissolved-sulfate concentration in the coastal sabkha aquifer of $4 \mathrm{~g} \mathrm{l}^{-1}$ (Table 2) suggests a loss of approximately $29 \mathrm{~g} \mathrm{l}^{-1}$ over time. This mass loss per liter is multiplied by the number of liters in the control volume, which results in a total loss from solution of $98,200 \mathrm{~g}$ in 7000 years. Assuming that all of this loss is due to the precipitation of anhydrite with a molecular weight of 136 , then a mass of $139,000 \mathrm{~g}$ would have been precipitated in our control volume since the Abu Dhabi aquifer was formed. As anhydrite has a density of $2.94 \mathrm{~g} \mathrm{~cm}^{-3}, 47,300 \mathrm{~cm}^{3}$ of pore space in our control volume is occluded by this mineral. A comparison of this volume to total pore space can be made using the following formula

$\theta_{\mathrm{f}}=V_{\min } / V_{\mathrm{tot}}$, where $\theta_{\mathrm{f}}$ is the fraction of total porosity occupied by anhydrite, $V_{\min }$ is the volume of minerals precipitated, and $V_{\text {tot }}$ is the total pore volume. If it is assumed that most of this loss occurs in a capillary zone that extends to $0.5 \mathrm{~m}$ above the water table, then the fraction of total porosity occupied by anhydrite is approximately $25 \%$, which is consistent with the observed mass of anhydrite.

The thermodynamic approach provides another independent estimate of the mass precipitated. In this approach, the geochemical code PHRQPITZ (Plummer et al., 1988) is used with a representative solute analysis of the water from the sabkha to calculate the amount of anhydrite precipitated at various temperatures. The flux rate of water vapor is between 0.15 and $0.2 \mathrm{~mm} /$ day, or approximately $65 \mathrm{~mm}$ annually. This rate does not vary significantly throughout the seasons of the year (Sanford and Wood, 2001). For a $1-\mathrm{m}^{2}$ surface area, this flux translates into $65 \mathrm{l} \mathrm{a}^{-1}$, or $75 \mathrm{~kg} \mathrm{a}^{-1}$, and represents the water flux that can be used in the calculations. Assuming that the average annual temperature of the capillary zone is $40{ }^{\circ} \mathrm{C}$, then it is possible to calculate a net anhydrite precipitation of approximately $0.26 \mathrm{~mol} \mathrm{a}^{-1} \mathrm{~m}^{3}$, or $35 \mathrm{a}^{-1} \mathrm{~m}^{3}$ (Fig. 5). Using a density of $2.94 \mathrm{~g} \mathrm{~cm}^{-3}$, approximately $12 \mathrm{~cm}^{3} \mathrm{a}^{-1} \mathrm{~m}^{3}$ of pore space is filled with anhydrite each year. Because this system has been operating for approximately 7000 years, a total of $84,500 \mathrm{~cm}^{3}$ of pore space would now be filled with anhydrite. Application of Eq. (2) suggests that approximately $45 \%$ of the available pore space in the capillary zone would be occupied by anhydrite. It is assumed that all of the sulfate is removed in the capillary zone (100\% efficient), which is not the case because minor amounts of sulfate occur in the surface salt crusts (Table 1). Thus, the $45 \%$ reduction in porosity is a maximum value and is consistent with the value of $25 \%$ calculated by the mass-balance method, considering the uncertainties of each method.

Sulfur-isotope data, expressed as $\delta^{34} \mathrm{SSO}_{4}$ (Table 3 ), are consistent with a closed system for $\mathrm{S}$. That is, loss of sulfate from the system would distort the isotopic ratio of the remaining solutes and minerals. The $\delta^{34} \mathrm{SO}_{4}$ is defined as:

$\delta^{34} \mathrm{SO}_{4 \mathrm{CDT}}=\left(R_{\text {sample }}-R_{\mathrm{CDT}}\right) /\left(R_{\mathrm{CDT}}\right) \times 1000$, 
Table 2

Chemical and isotopic analyses of selected samples

\begin{tabular}{|c|c|c|c|c|c|c|c|c|c|c|c|c|c|c|c|c|c|c|c|c|}
\hline Field numbers & $\begin{array}{l}\text { UTM } \\
\text { east }\end{array}$ & $\begin{array}{l}\text { UTM } \\
\text { north }\end{array}$ & $\begin{array}{l}\text { UTM } \\
\text { zone }\end{array}$ & $\begin{array}{l}\text { M Date } \\
\text { sampled }\end{array}$ & $\begin{array}{l}\mathrm{Ca} \\
\left(\mathrm{mg} \mathrm{1^{-1 }}\right)\end{array}$ & $\begin{array}{l}\mathrm{Mg} \\
\left(\mathrm{mg}^{-1}\right)\end{array}$ & $\begin{array}{l}\mathrm{Na} \\
\left.{ }^{1}\right)\left(\mathrm{mg}^{-1}\right)\end{array}$ & $\begin{array}{l}\mathrm{K} \\
\left.{ }^{1}\right)\left(\mathrm{mg}^{-1}\right)\end{array}$ & $\begin{array}{l}\mathrm{Sr} \\
\left.{ }^{1}\right)\left(\mathrm{mg} \mathrm{1}^{-}\right.\end{array}$ & $\begin{aligned} & \mathrm{SiO}_{2} \\
&\left(\mathrm{mg} \mathrm{l}^{-1}\right. \\
&\end{aligned}$ & $\begin{array}{l}\text { Alk } \\
-1) \mathrm{HCO} \\
\end{array}$ & $\begin{array}{l}\mathrm{Cl} \\
3\left(\mathrm{mg} \mathrm{1}^{-1}\right)\end{array}$ & $\begin{array}{l}\mathrm{SO}_{4} \\
)\left(\mathrm{mg} \mathrm{1}^{-1}\right. \\
\end{array}$ & $\begin{array}{l}\mathrm{NO}_{3} \\
\left.{ }^{1}\right)\left(\mathrm{mg} \mathrm{l}^{-1}\right)\end{array}$ & $\begin{array}{l}\mathrm{Br} \\
)\left(\mathrm{mg} \mathrm{1}^{-1}\right.\end{array}$ & $\begin{array}{l}\text { B } \\
1)\left(\mu \mathrm{g} \mathrm{l}^{-1}\right)\end{array}$ & $\begin{array}{l}\mathrm{Ba} \\
\left(\mu \mathrm{g}^{-1}\right)\end{array}$ & $\begin{array}{r}\text { Density } \\
-1) \text { at } 20^{\circ} \mathrm{C} \\
\end{array}$ & 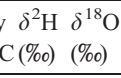 & $\begin{array}{l}\delta^{37} \mathrm{Cl} \text { pH Dissolved } \\
(\% \circ) \quad \text { solids }\end{array}$ \\
\hline \multicolumn{21}{|c|}{ Coastal sabkha aquifer } \\
\hline ABU-007 & 25130 & 92669821 & 140 & 29-Dec-97 1 & 12,900 & 13,400 & 83,000 & 5550 & 220 & 51 & 13 & 200,000 & 750 & 2000 & 130 & 3300 & 760 & 1.2127 & 31.98 .83 & $0.076 .1318,000$ \\
\hline ABU-012 & 250900 & 02688981 & 140 & 30-Dec-97 & 8250 & 14,400 & 81,500 & 4800 & 200 & 41 & 16 & 190,500 & 900 & 1700 & 35 & 1200 & 480 & 1.2033 & 25.36 .05 & $0.386 .5302,300$ \\
\hline ABU-017 & 235103 & 32678219 & 940 & 30-Dec-97 4 & 40,000 & 31,000 & 40,300 & 13,600 & 900 & 101 & 20 & 240,000 & 200 & 8400 & 50 & 880 & 2300 & 1.2622 & 27.36 .76 & $0.365 .6374,370$ \\
\hline ABU-024 & 238042 & 22675163 & 340 & 4-Jan-98 1 & 15,800 & 17,900 & 71,500 & 7100 & 225 & 56 & 12 & 197,000 & 650 & 4400 & 15 & 1300 & 480 & 1.2120 & 28.97 .12 & $-0.206 .0314,700$ \\
\hline IAT-001 & 578676 & 62649822 & & 9-Dec-97 & 2900 & 5800 & 88,000 & 2650 & 90 & 26 & 8.5 & 166,000 & 2500 & 650 & 80 & 7000 & 640 & 1.1828 & & $-0.066 .5268,700$ \\
\hline MAT-026 & 619365 & 92647143 & 339 & 16-Dec-97 & 5600 & 7700 & 92,000 & 4200 & 140 & 32 & 32 & 177,000 & 1700 & 140 & 85 & 2800 & 340 & 1.1862 & & $0.316 .5288,600$ \\
\hline MAT-038 & 628002 & 22646412 & 239 & 17-Dec-972 & 26,900 & 20,500 & 64,500 & 6250 & 700 & 60 & 21 & 204,000 & 250 & 14,700 & 20 & 2400 & 2100 & 1.2245 & & $-0.046 .1337,900$ \\
\hline GWP 287c & 600314 & 42647259 & 939 & Feb-98 & 2000 & 1775 & 21,000 & 775 & 35 & 21 & 79 & 36,500 & 4300 & 315 & & 8350 & 25 & 1.0452 & 17.86 .12 & $0.09 \quad 67,300$ \\
\hline $\begin{array}{l}\text { GWP 288b } \\
\text { GWP 288b }\end{array}$ & 687881 & 12666667 & 739 & Feb-98 & 3500 & 3750 & 63,000 & 1450 & 65 & 29 & 45 & 105,000 & 2800 & 1100 & & 7500 & 90 & 1.1312 & 26.47 .83 & $\begin{array}{l}-0.197 .6186,800 \\
-0.30\end{array}$ \\
\hline $\begin{array}{l}\text { GWP 288b } \\
\text { GWP 291b }\end{array}$ & $20554 C$ & 02670460 & & Feb-98 & & & 81,500 & & & & & & & 33 & & & & & 27.36 .27 & $\begin{array}{l}-0.30 \\
0.437 .4256,000\end{array}$ \\
\hline $\begin{array}{l}\text { GWP 29lb } \\
\text { Average of } 192\end{array}$ & & & & & 11,250 & 10,000 & 82,120 & 4240 & 262 & 52 & 56 & 176,350 & 3920 & 3550 & 80 & & & 1.1896 & & $6.6291,930$ \\
\hline $\begin{array}{l}\text { analyses of } \\
\text { sabkha }\end{array}$ & & & & & & & & & & & & & & & & & & & & \\
\hline \multicolumn{21}{|c|}{ Tertiary brine inout } \\
\hline jWP 288a & 687801 & $12666 t$ & 939 & Feb-9 & 145 & 950 & 10,50 & & 2 & 3 & 55 & & 40 & 33 & 11 & 23,0 & 20 & & -6.2 & $0.128 .0 \quad 37,110$ \\
\hline 289 & 77765 & 26 & & Feb- & & 6 & & 12 & 2 & & 4 & & 400 & 8 & 5 & 425 & 10 & & 0.72 .92 & $-0.107 .821,900$ \\
\hline GWP 290 & 2111 & 026552 & & Feb- & 150 & 950 & 15,500 & 450 & 27 & 20 & 50 & 25,000 & 6750 & 22 & 15 & 9250 & 10 & 1.0369 & 5.94 .09 & $0.167 .4 \quad 50,280$ \\
\hline GWP 291a & $20554 c$ & 02670460 & & Feb-98 & 2200 & 1350 & 31,500 & 950 & 40 & 18 & 39 & 55,100 & 4650 & 35 & 20 & 10,500 & 5 & 1.0686 & 5.04 .64 & $0.447 .8 \quad 95,900$ \\
\hline WP 291a & & & & & & & & & & & & & & & & & & & & 0.35 \\
\hline GWP-292 & 23694 & 52671480 & 040 & Feb-98 & 3600 & 2400 & 48,000 & 1500 & 62 & 23 & 34 & 87,300 & 3300 & 33 & 6 & 14,700 & 15 & 1.0971 & 7.55 .19 & $-0.017 .4146,300$ \\
\hline
\end{tabular}


Table 3

Sulfur-isotope values of solutes

\begin{tabular}{|c|c|c|c|c|c|c|c|}
\hline Site number & UTM east & UTM north & UTM zone & Date sampled & $\mathrm{SO}_{4}\left(\mathrm{mg} \mathrm{l}^{-1}\right)$ & $\delta^{34} \mathrm{~S}(\% 0)$ & Depth (m), BLS \\
\hline \multicolumn{8}{|c|}{ Coastal sabkha solutes } \\
\hline ABU 024 & 238042 & 2675163 & 40 & 03-Jan-98 & 650 & 18.9 & 2 to 3 \\
\hline ABU 039 & 214202 & 2666488 & 40 & 05-Jan-98 & 850 & 16.9 & 2 to 3 \\
\hline ABU 134 & 253864 & 2663357 & 40 & 23-Mar-98 & 950 & 14.4 & 2 to 3 \\
\hline ABU 195-S & 211348 & 2664564 & 40 & 24-Mar-98 & 950 & 14.0 & 2 to 3 \\
\hline GWP 287-C & 600314 & 2647259 & 39 & Feb-98 & 4300 & 18.4 & 5 to 6 \\
\hline GWP 288-B & 687811 & 2666667 & 39 & Feb-98 & 2800 & 16.9 & 5 to 6 \\
\hline MAT 015 & 598286 & 2631893 & 39 & 08-Dec-97 & 750 & 15.5 & 2 to 3 \\
\hline MAT 041 & 619337 & 2636708 & 39 & 21-Dec-97 & 600 & 13.0 & 2 to 3 \\
\hline MAT 049 & 610965 & 2623284 & 39 & 21-Dec-97 & 100 & 14.7 & 2 to 3 \\
\hline RUW 010 & 638992 & 2656711 & 39 & 13-Dec-97 & 1000 & 16.1 & 2 to 3 \\
\hline RUW 033 & 688683 & 2667926 & 39 & 02-Mar-98 & 1200 & 14.1 & 2 to 3 \\
\hline RUW 048 & 712600 & 2667300 & 39 & 11-Mar-98 & 4000 & 13.9 & 2 to 3 \\
\hline TAR 004 & 796039 & 2661669 & 39 & $15-F e b-98$ & 1150 & 18.2 & 2 to 3 \\
\hline \multicolumn{7}{|c|}{ Tertiary brine input } & $-\mathrm{cm}-$ \\
\hline GWP-288A & 687801 & 2666649 & 39 & Feb-98 & 4050 & 19.8 & 89 \\
\hline GWP-289 & 777587 & 2655712 & 39 & Feb-98 & 4000 & 19.8 & 119 \\
\hline GWP-290A & 210989 & 2655365 & 40 & Feb-98 & 6750 & 17.7 & 88 \\
\hline GWP-291A & 205481 & 2670574 & 40 & Feb-98 & 4650 & 18.4 & 142 \\
\hline GWP-292 & 236909 & 2671579 & 40 & Feb-98 & 3300 & 17.8 & 119 \\
\hline \multicolumn{8}{|c|}{ Sabkha anhydrite } \\
\hline Site 1 & 207444 & 2668779 & 39 & 12-May-97 & - & 20.5 & $0.010-.038$ \\
\hline Site 1 & 207444 & 2668779 & 39 & 12-May-97 & - & 20.1 & $0.013-.018$ \\
\hline Site 1 & 207444 & 2668779 & 39 & 12-May-97 & - & 19.8 & 0.027 \\
\hline Site 2 & 203552 & 2673333 & 39 & 12-May-97 & - & 20.4 & $0.0-.015$ \\
\hline Site 2 & 203552 & 2673333 & 39 & 12-May-97 & - & 21.3 & $0.089-.109$ \\
\hline Site 2 & 203552 & 2673333 & 39 & 12-Мay-97 & - & 21.2 & $0.134-.147$ \\
\hline Site 4 & 209275 & 2660028 & 39 & 13-Мay-97 & - & 17.2 & $0.0-.015$ \\
\hline Site 4 & 209275 & 2660028 & 39 & 13-May-97 & - & 17.2 & $0.030-.046$ \\
\hline Site 4 & 209275 & 2660028 & 39 & 13-May-97 & - & 17.2 & $0.058-.073$ \\
\hline
\end{tabular}

where $R_{\text {sample }}$ is ${ }^{34} \mathrm{SO}_{4} /{ }^{32} \mathrm{SO}_{4}$ of the sample, and $R_{\mathrm{CDT}}$ is ${ }^{34} \mathrm{SO}_{4}{ }^{\beta 2} \mathrm{SO}_{4}$ of the standard Canyon Diablo troilite (CDT). Samples in Table 3 were collected and analyzed by methods described in Wood et al. (2002) and illustrate the similarity of results over a large geographic area.

It is known from isotopic fractionation experiments that gypsum precipitated from a solution will be about $1.65 \%$ o (per mil) heavier than input, and that the sulfate remaining in solution will be about $1.65 \%$ o lighter than the input (Thode and Monster, 1965). Analyses in Table 3 indicate that the average of five samples of Tertiary brine is $18.7 \%$. Thus, anhydrite or gypsum that precipitates in the unsaturated zone should average approximately $20.35 \%$ and the sulfate remaining in solution in the $\mathrm{Abu}$ Dhabi aquifer should average $17.0 \%$ o. It is seen in Table 3 that the average of 9 samples of these minerals from the unsaturated zone is $20.0 \%$, and the average of 13 samples of sulfate from the Abu Dhabi aquifer is $15.8 \%$. The observed values are close to those predicted by fractionation from the Tertiary brines and are consistent with the model that little sulfate has been lost from the system. The isotopic values from the sediments differ from those reported by Butler et al. (1973) because the samples were collected outside the supratidal zone examined by Butler et al. (1973), and thus they do not have the seawater isotopic signature.

A mass-balance calculation for $\mathrm{Cl}$ and $\mathrm{Na}$ similar to that above suggests that there should be a layer of halite approximately $30 \mathrm{~cm}$ thick on the surface. Commonly, there is less than $1 \mathrm{~cm}$ and none in the capillary zone or below the water table. Thus, the system has lost a significant amount of $\mathrm{Na}$ and $\mathrm{Cl}$. Fig. 6, plotted from analyses of 192 samples of water collected from representative areas of the coastal sabkha (Fig. 1), shows the evolution and loss of $\mathrm{Na}$ 


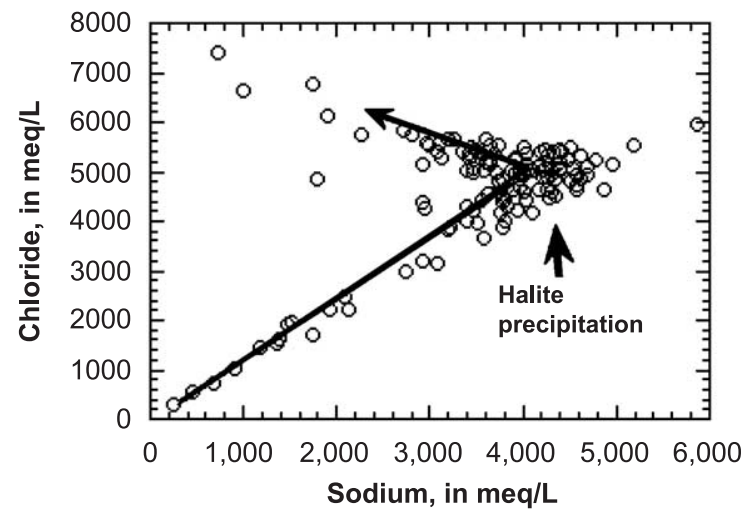

Fig. 6. Milliequivalents per liter (meq $\mathrm{l}^{-1}$ ) of $\mathrm{Na}$ as a function of meq $1^{-1}$ of $\mathrm{Cl}$ illustrates the evolution of $\mathrm{Na}$ concentration in the sabkha of the Emirates of Abu Dhabi.

(halite) from solution. Calculating the amount of halite loss from the concentration ratio of a given solute provides a means of estimating loss (Fig. 7), as shown in the following equation:

$\mathrm{CR}=C_{\mathrm{obs}} / C_{\mathrm{in}}$,

where $\mathrm{CR}$ is the concentration ratio, $C_{\mathrm{obs}}$ is the observed solute concentration, and $C_{\text {in }}$ is the solute concentration of input solute.

It is known that the concentration ratio in the $\mathrm{Abu}$ Dhabi sabkha aquifer is approximately 7 for essentially conservative solutes, such as $\mathrm{Br}$ and $\mathrm{Mg}$ (Fig. 7; Table 2). Conversely, the concentration ratio for $\mathrm{Na}$ is 3.5 (Fig. 7). This difference in concentration ratio is most easily explained by assuming that approximately one-half of the $\mathrm{Na}$ has been removed from solution by precipitation as halite. Because there is little halite in the system, it is concluded that the system is chemically open with respect to $\mathrm{Na}$ and $\mathrm{Cl}$.

Isotopes of $\mathrm{Cl}$ can also provide insight into the evolution of $\mathrm{Cl}$ in this system. The $\delta^{37} \mathrm{Cl}$ isotope is defined as follows:

$\delta^{37} \mathrm{Cl}_{\mathrm{SMOC}}=\left(R_{\text {sample }}-R_{\mathrm{SMOC}}\right) /\left(R_{\mathrm{SMOC}}\right) \times 1000$,

where $R_{\text {sample }}$ is ${ }^{37} \mathrm{Cl} /{ }^{35} \mathrm{Cl}$ of the sample, and $R_{\mathrm{SMOC}}$ is ${ }^{37} \mathrm{Cl} /{ }^{35} \mathrm{Cl}$ of the standard SMOC (Standard Mean Ocean Chlorine). The value of $\delta^{37} \mathrm{Cl}$ was calibrated using seawater (Atlantic Ocean), which has been matched to the worldwide seawater standards of

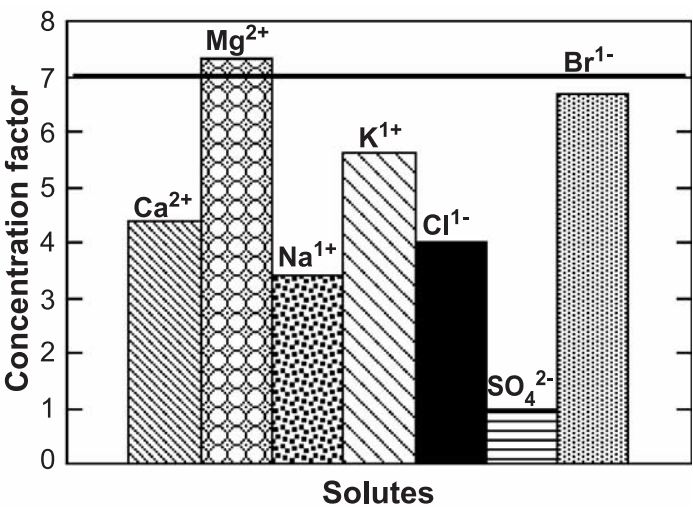

Fig. 7. Concentration factor (ratio of existing concentration in the sabkha aquifer to input concentration of Tertiary brines) of the coastal sabkha aquifer of the Emirates of Abu Dhabi. Line at a concentration factor of 7 is that calculated from physical hydrological information (modified from Wood et al., 2002).

Kaufman et al. (1984). Filtered, unacidified water samples were used for $\delta^{37} \mathrm{Cl}$ analyses. Chloride in solution was removed as silver chloride using silver nitrate and converted to methyl chloride, according to the method described by Long et al. (1993). Pretreatment to remove sulfate was not observed to affect the final result. Methyl chloride samples were analyzed using a VG SIRA 9 mass spectrometer. The triple collector geometry allows for the measurement of individual SO and S2 mass peaks. Analytical precision of the technique in use for this study was $\pm 0.15 \%$. Results of these analyses are presented in Table 2.

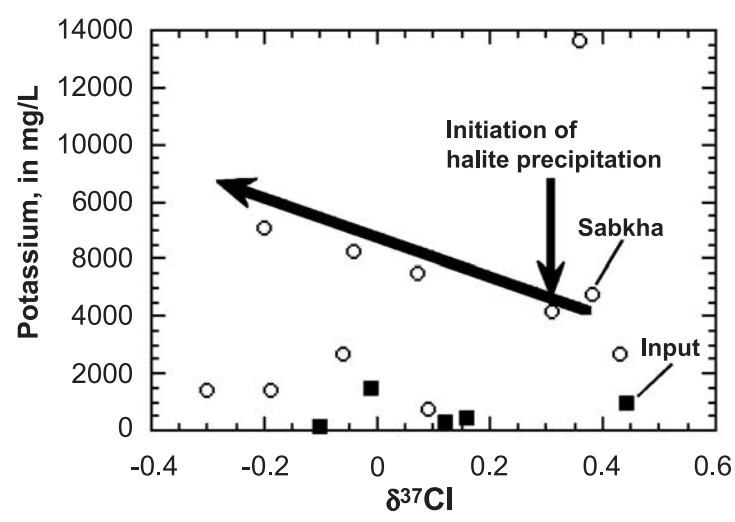

Fig. 8. Chlorine isotopes versus concentration of $\mathrm{K}$ of both sabkha (O) and input Tertiary brine (匹) from Table 2 illustrate the decrease in isotopic value with increasing concentration of $\mathrm{K}$ once halite precipitation has commenced. 
The dissolved $\mathrm{Cl}$ becomes isotopically lighter with increasing concentration of $\mathrm{K}$ (Fig. 8), consistent with the precipitation of halite and preferential removal of ${ }^{37} \mathrm{Cl}$ relative to ${ }^{35} \mathrm{Cl}$. Concentrations of $\mathrm{K}$ that are $<3000 \mathrm{mg} \mathrm{l}^{-1}$ and that have $\delta^{37} \mathrm{Cl}$ ranging from -0.2 to 4.0 represent input values that are concentrated by evaporation, but no mechanism is operating to cause isotopic fractionation. It is only after the start of precipitation of halite that $\delta^{37} \mathrm{Cl}$ becomes more negative with increasing concentration of K (Long et al., 1993; Fig. 8). Although the value of $\delta^{37} \mathrm{Cl}$ by itself does not assist with defining an open system, the observation that it changes has important ramifications for interpreting the isotopic record of $\mathrm{Cl}$ in sabkha sediments.

\section{Mechanisms of mass loss from the system}

The mechanism or combination of mechanisms by which halite is lost from the surface is not known with certainty. Halite may be removed from the surface by eolian processes or by dissolution and transport to the Arabian Gulf. Because the halite on the sabkha is more "ice-like" than the loose, fine powder common with $\mathrm{Na}$ sulfates or Na carbonates, it is not as mobile in an eolian setting. Two sets of eolian samplers $100 \mathrm{~km}$ apart did detect some mass transport in the 2 years of the study; however, data collection was poor, and the results are not definitive. The concentration ratios for $\mathrm{Mg}$ and $\mathrm{K}$ ions are different from those of $\mathrm{Na}$ and $\mathrm{Cl}$ (Fig. 7), suggesting selective removal rather than the loss of all surface salts (Table 1) that would be expected to occur by eolian erosion.

Solute transport into the adjacent Arabian Gulf could occur either by flooding of Gulf water or by rainfall runoff. Because the halite is missing over the entire area, not just seaward of the high stand of the supratidal zone, located approximately $3 \mathrm{~km}$ inland, encroachment by Gulf floodwater does not appear to be a viable mechanism for surface-salt removal. The annual rainfall along the coast averages $60 \mathrm{~mm}$; however, it is known that approximately $100 \mathrm{~mm}$ of rain occurred once in a 24-h period in the 35 years for which records exist (Bottomley, 1996). It is concluded that the most likely scenario for removing the soluble surface crust is the intense but infrequent rainfall events that dissolve and transport salts to the Arabian Gulf.
A check on the reasonableness of this explanation for halite dissolution by intense rainfall is obtained by calculating the amount of halite that could be dissolved with a $100-\mathrm{mm}$ rainfall. Consider a surface area $1 \mathrm{~m}^{2}$. It is known that $\mathrm{Cl}$ concentration in equilibrium with halite in this system, from Fig. 6, is approximately $142,000 \mathrm{mg}^{-1}$. One hundred millimeters of rain is equivalent to 1001 on the $1 \mathrm{~m}^{2}$ control surface area. Thus, the dissolution potential is $14,200 \mathrm{~g}$ of $\mathrm{Cl}$, or $21,900 \mathrm{~g}$ of halite. Halite has a density of $2.16 \mathrm{~g} \mathrm{~cm}^{-3}$, so approximately $10,100 \mathrm{~cm}^{3}$ of halite could be removed, or a thickness of approximately $1 \mathrm{~cm}$ on the $1-\mathrm{m}^{2}$ control area. It is known from the analysis above that approximately $30 \mathrm{~cm}$ of halite are missing. Thus, it would take only one $100 \mathrm{~mm} /$ day rainfall to occur once in every 230 years of the 7000 years the system has existed, to remove the halite. Only 35 years of rainfall data exist, but it seems probable that the $100 \mathrm{~mm} /$ day rainfall occurs more frequently than once in 230 years. Thus, the proposed rainfall-dissolution-transportation mechanism is not constrained by dissolution potential.

The observation that the concentration ratios of $\mathrm{K}$, $\mathrm{Mg}$, and $\mathrm{Br}$ are closer to the input values is also consistent with the rainfall-dissolution model. If the salts were removed by eolian activity, all salts would be removed in equal ratios, which is not observed. The following model is thus proposed: the more soluble minerals, such as carnallite, sylvite, and antarcticite, would be the first to dissolve, and thus selectively recharged relative to $\mathrm{NaCl}$ in any recharge event. The presence of only a small volume of storage in the capillary zone limits the amount of water that can be recharged in any one event because the first water in a recharge event fills the available space, and the rest is rejected. With continued rain, the pools in the polygons coalesce and flow down-gradient toward the Gulf, removing the less soluble halite. The net result is that there is a lack of mass balance among the $\mathrm{Na}, \mathrm{K}, \mathrm{Mg}$, and $\mathrm{Ca}$ present in the sabkha relative to the input solutes.

\section{Summary and conclusions}

The conceptual model developed above suggests that water and solutes are transported upward by capillary force from the shallow water table in response to evaporation of water at the surface. The water is 
removed, thereby precipitating halite, carnallite, antarcticite, and other soluble minerals. Minerals exhibiting retrograde solubility, however, such as anhydrite, calcite, dolomite, and gypsum, are precipitated below the surface as a result of increasing temperature as the solutes move from the groundwater through the capillary zone toward the surface during the summer months. The difference in thermal gradient between the winter and summer months is consistent with the net accumulation of these minerals over time in the capillary zone. Because these minerals are rather insoluble relative to halite and other chloride and nitrate minerals, and are precipitated below the surface, they are less likely to be dissolved and transported to the Gulf by rainfall, and thus they are preserved selectively relative to the soluble salts on the surface.

The observations above are important in evaluating the solute environment responsible for the chemical sediments preserved in the geological record. That is, the system is chemically open for $\mathrm{Cl}$ and closed for $\mathrm{S}$, and the mass of a given mineral preserved depends upon factors other than the original solute composition. Mineral development in the coastal sabkha is conceptually similar to the leaky-basin model (open system) used to understand mineral development in evaporating basins (Wood and Sanford, 1990; Sanford and Wood, 1991) and contrasts with the closed system approach of Hardie and Eugster (1970). The preferential loss of halite, and possibly other soluble minerals, from this system is important in understanding the evolution of solute chemistry and mineral development in coastal sabkhat and has implications for evaluating coastal-sabkha facies and environments in the geological record. It is important to note that the system can be closed for one element and open for another, and likewise that water may be derived from one source and solutes from another. Because of these factors, care must be used in interpreting the solute environment of a coastal sabkhat solely on the basis of the mineralogical record.

\section{Acknowledgments}

We thank Mohamed B. Al-Qubaisi, Abu Dhabi National Oil Company, UAE, for his interest and support, and John Czarnecki, U. S. Geological Survey (USGS), for installing the temperature probes and supervising the collection of the temperature data. We also thank Thomas Kraemer, USGS, and Duncan Sibley, Michigan State University, for their efforts in the early review process. Sibley also provided X-ray analyses of some of the minerals. Jeffery Hanor, Michael Rosen, and Robert Seal provided insightful and helpful reviews. Publication is approved by the Director of the USGS and the Abu Dhabi National Oil Company. The investigation was fully funded by $\mathrm{Abu}$ Dhabi National Oil Company. [PD]

\section{References}

Bottomley, N., 1996. Recent climate in Abu Dhabi. In: Osborne, P.E. (Ed.), Desert Ecology of Abu Dhabi. Pisces Publications, Newbury, UK.

Butler, G.P., 1969. Modern evaporite deposition and geochemistry of coexisting brines, the sabkha, Trucial Coast, Arabian Gulf. J. Sediment. Petrol. 39, 70-81.

Butler, G.P., Krouse, R.H., Mitchell, R., 1973. Sulphur-isotope geochemistry of an arid, supratidal evaporite environment, Trucial Coast. In: Purser, B.H. (Ed.), The Persian Gulf. Springer-Verlag, Berlin, pp. 453-462.

Evans, G., 1995. The Arabian Gulf-a modern carbonate-evaporite factory; a review. Cuadernos de Geologia Iberica, vol. 19. Servicio de Publicaciones, Universidad Complutense, Madrid, pp. $61-95$.

Gary, M., McAfee, R., Wolf, C.L. (Eds.), Glossary of Geology. American Geological Institute, Washington, DC.

Hardie, L.A., Eugster, H.P., 1970. The evolution of closedbasin brines. Mineral. Soc. Am. Spec. Publ. 3, 273-290.

Kaufman, R., Long, A., Bentley, H., Davis, S., 1984. Natural chlorine isotope variation. Nature 309, 338-340.

Kinsman, D.J.J., 1969. Modes of formation, sedimentary associations, and diagnostic features of shallow-water and supratidal evaporites. Am. Assoc. Pet. Geol. Bull. 53, 830-840.

Long, A., Eastoe, C., Kaufman, R.S., Martin, J.G., Wirt, L., Finley, J.B., 1993. High-precision measurements of chlorine stable isotope ratios. Geochim. Cosmochim. Acta 57, 2907-2912.

McKenzie, J.A., Hsü, K.J., Schneider, J.F., 1980. Movement of subsurface waters under the sabkha, Abu Dhabi, UAE, and its relation to evaporative dolomite genesis. SEPM Spec. Publ. 28, $11-30$.

Plummer, L.N., Parkhurst, D.L., Fleming, G.W., Dunkle, S.A., 1988. A computer program incorporating Pitzer's equations for calculation of geochemical reactions in brines. U.S. Geol. Surv. Water-Resources Invest. Rep. 88-4153.

Rosen, M.R., 1994. The importance of groundwater in playas: a review of playa classifications and the sedimentology and hydrology of playas. Spec. Pap.-Geol. Soc. Am. 289, 1-18.

Sanford, W.E., Wood, W.W., 1991. Brine evolution and mineral deposition in hydrologically open evaporite basins. Am. J. Sci. 291, 687-710. 
Sanford, W.E., Wood, W.W., 2001. Hydrology of the coastal sabkhas of Abu Dhabi, United Arab Emirates. Hydrogeol. J. 4, 358-366.

Smoot, J.P., Lowenstein, T.K., 1991. Depositional environments of non-marine evaporites. In: Melvin, J.L. (Ed.), EvaporitesPetroleum and Mineral Resources, Developments in Sedimentology, vol. 50. Elsevier, Amsterdam, pp. 189-347.

Thode, H.G., Monster, J., 1965. Sulfur-isotope geochemistry of petroleum, evaporites, and ancient seas. Am. Assoc. Pet. Geol. Bull. 4, 367-377.
Wood, W.W., Sanford, W.E., 1990. Groundwater control of evaporite deposition. Econ. Geol. 85, 1226-1235.

Wood, W.W., Sanford, W.E., Al Habshi, A.R.S., 2002. The source of solutes to the coastal-sabkha aquifer of Abu Dhabi. Geol. Soc. Amer. Bull. 114, 259-268. 